SCIREA Journal of Hydraulic Engineering http://www.scirea.org/journal/Hydraulic

May 24, 2021

Volume 4, Issue 1, February 2021

\title{
THE INFLUENCE OF VARIATION OF WEIR CREST SHAPE WITH USBR-I TYPE OF STILLING BASIN ON THE LENGTH OF HYDRAULIC JUMP AND LOSS OF ENERGY
}

\author{
Jaji Abdurrosyid ${ }^{1, *}$, Edi Purwanto ${ }^{1}$, and Renaningsih ${ }^{1}$ \\ ${ }^{1}$ Departement of Civil Enginnering, Engineering Faculty, Universitas Muhammadiyah \\ Surakarta, Jl. Ahmad Yani tromol pos1, Pabelan Surakakarta 57102, Indonesia \\ *Corresponding author: ja199@ums.ac.id, Cc: jajiabdurrosyid@gmail.com
}

\begin{abstract}
The Crest of weir is an important part of dam construction because the function is releasing water from the upstream part of the dam. The effect of a dam can create supercritical flow (supercritical) downstream of the weir and cause a water jump (hydraulic jump) which if left untreated will occur local scour the downstream. weir. In weir planning, it is necessary to take into the dam will be used because it affects the flow conditions downstream of the weir. This research was conducted by making variations in the form of test objects, namely ogee crest weirs, 1 radius round type weirs, and 2 radius round type weirs using the USBR-I stilling basin type which was then tested in the laboratory using five different variations of flow rates, namely $3000 \mathrm{~cm}^{3} / \mathrm{s}, 3500 \mathrm{~cm}^{3} / \mathrm{s}, 4000 \mathrm{~cm}^{3} / \mathrm{s}, 4500 \mathrm{~cm}^{3} / \mathrm{s}$, and $5000 \mathrm{~cm}^{3} / \mathrm{s}$. The data test was analyzed to obtain results of research and compared with the crest variations to find the best efficient to reduce energy and length of hydraulic jump. The results in the study show the
\end{abstract}


effect of dam crest variations on the length of the hydraulic jump ( $\mathrm{Lj})$ based on the maximum discharge, which is round type 1 radius of dam crest with $125 \mathrm{~cm}$ longest $\mathrm{Lj}$, then a 2 radius round type with the longest $\mathrm{Lj} 136 \mathrm{~cm}$, and an ogee type with the longest $\mathrm{Lj} .142 \mathrm{~cm}$. For the effect of variations of dam crest on energy loss (hf), the average value of the five running discharge experiments on each specimen was taken, the variation of the dam crest that had the greatest to the smallest energy loss (hf) value was the 2 radius round type dam with $\mathrm{hf}$ average $31,429 \mathrm{~cm}$, ogee type dam with an average hf of $31.404 \mathrm{~cm}$, and round type 1 radius dam with an average $\mathrm{hf}$ of $30.456 \mathrm{~cm}$. So it can be concluded based on the results of the analysis for the variation of the dam crest that is the most efficient in reducing energy is the 2 radius round type dam crest.

Keywords: crest of weir, hydraulic jump, energy loss.

\section{INTRODUCTION}

Indonesia is one of the largest agricultural countries in the world. On many occasions, problems arise in the agriculture sector, such as desertification due to prolonged dry seasons and inefficient water distribution for land irrigation. To deal with these problems, it requires proper management of water resources by constructing a weir on the river to regulate the efficiency of water flowing from upstream to downstream. Weir is a water structure built across a river or channel to increase the water level which will be flowed to the irrigation network (Abdurrosyid, et.all.) [1]. It is worth noting that the dam may create a heavy (supercritical) flow downstream of the weir and cause a hydraulic jump as the effects which, if left untreated, will result in scouring around the downstream of the weir. To reduce the scouring process, stilling basin is planned and the most effective form of weir construction is built to reduce the energy flow.

The purpose of this study was to determine the effect of shape variations of weirs and stilling basin type USBR-I on the length of the hydraulic jump and energy loss. This research is expected to a reference in weir construction planning, particularly in planning the weir type as well as a reference to choose the most effective type for weir construction in reducing the energy flow and the length of the jump. The types of the weir are Ogee type, Round-Crest 1 Radius (R1), and Round-Crest 2 radius ( $\mathrm{R} 1$ and $\mathrm{R} 2$ ). 
Previous studies examining the type of weir, energy dissipation, and hydraulic jump include (Abdurrosyid and Pratiwi, 2020) [2] who conducted research on energy dissipation and hydraulic jumps on weirs with Ogee weir and stilling basin type solid roller bucket equipped with slotted and baffle blocks with title "Study of the Effect of Slotted and Baffle Blocks in the Energy Dissipation of Stilling Basin Type Roller Bucket ". The results showed that stilling basin type roller bucket with half-round slotted and concave type baffle blocks was the most effective against stream impact forces, reduced stream turbulence reduced the length of hydraulic jump, and dissipated energy.

Abdurrosyid, et. all. 2018 [1] conducted a study on the effect of variations in the weir slope of the downstream and the placement of baffle blocks in the stilling basin type solid roller bucket on hydraulic jumps and energy dissipation. It resulted in several conclusions; first, the most effective arrangement of buffle blocks in dissipating turbulence and hydraulic jumps in the downstream vortex was the one installed in the middle of the arched sharp-crest. Second, the efficiency of energy loss increased as the discharge variation decreased, the treatment without buffle blocks was the most efficient. Third, with the same flow rate from the variation of weir slope downstream, there was no significant difference in flow turbulence and energy loss except for the length of the hydraulic jump, showing that the 1: 1 slope was the most effective. Risman, et all. (2017) [3] conducted research on the study of flow behavior using a discharge instrument of round-crested weir on the water level. The results of this study found that the relationship between discharge and the water level upstream, the water level downstream, the water level above threshold, and the discharge coefficient of round-crested weir measuring instrument had a similar trend. The relation between the discharge and the discharge coefficient on a round-crested weir with weir crest of $\mathrm{R}=1.25$ units and $\mathrm{R}=1.5$ units had a similar trend, but $\mathrm{R}=1.0$ unit $(1 \mathrm{unit}=1 \mathrm{~cm}$ ) showed a different trend.

Ihsan (2017) [4] probed a study on the effect of the shape of the weir on the jumping height of the stilling basin USBR-IV model (laboratory simulation). The results concluded that the amount of the discharge, the slope of the channel bottom, and the difference in the shape of the weir affected the height of hydraulic jump. The height of hydraulic jump on round-crested weir was higher than hydraulic jump on the width threshold. In comparison, the height of hydraulic jump over the stilling basin on width threshold was higher than that of the roundcrested weir at the same discharge and slope. 
Nurjanah (2014) [5] analyzed the height and length of hydraulic jump in the construction of an arched sharp-crested weir. The results of the study indicated that the length of hydraulic jump and the height of hydraulic jump was influenced by the cross-sectional diameter and velocity, in which the smaller the cross-sectional diameter and the greater the velocity, the longer the length of hydraulic jump occurs and the lower the height is. Meanwhile, large cross-sectional diameter with a small velocity will result in a smaller length of hydraulic jump and an increased height.

\section{THEORETICAL THEORY}

Discharge is the amount of water flowing at a certain outlet in units of volume per time $\left(\mathrm{m}^{3} / \mathrm{s}\right)$ which is formulated as follows:

$$
\mathrm{Q}=\mathrm{A} \cdot \mathrm{V}
$$

Where :

Q : Flow rate $\left(\mathrm{cm}^{3} / \mathrm{s}\right)$

A : Wetted cross-sectional area $\left(\mathrm{cm}^{2}\right)$

$\mathrm{V} \quad$ : Velocity $(\mathrm{cm} / \mathrm{s})$

Weir is the uppermost part of the spillway, which is interrelated to the flowing water. Hence, the construction of weir affects the flow characteristics downstream. Commonly, Indonesia uses two types of spillway weir, which are round crest and Ogee type (Irrigation Planning Standards, KP-02, 2015) [6].

The ogee type weir is a flow nape of the sharp threshold weir. Therefore, once the weir drains water in the design discharge, the ogee-type weir will not exert atmospheric pressure on the surface of the weir (Novak P., et. All., 1996; Abdurrosyid, 2009). [7, 8] 


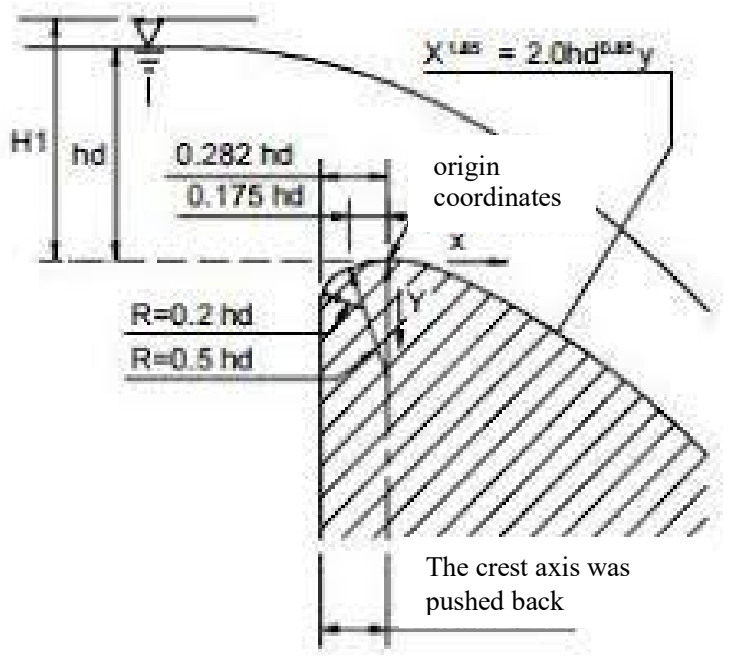

Figure 1. Cross-section of Ogee Type Weir (Source: Novak P., et all., 1996) [7]

In planning, there are definite equations used to determine the downstream slope (USBR, 1987) [9] namely:

$$
\frac{Y}{h_{d}}=\frac{1}{K}+\left(\frac{X}{h_{d}}\right)^{n}
$$

Where :

$\mathrm{X}$ and $\mathrm{Y}=$ coordinates of the downstream surface.

hd $\quad=$ height of energy plan above the weir.

$\mathrm{K}$ and $\mathrm{n}=$ Parameters depend on the slope factor of the weir upstream surface.

Table 1: Values of $K$ and $n$

\begin{tabular}{|c|c|c|}
\hline Upstream Slope & $\mathbf{K}$ & $\mathbf{n}$ \\
\hline Vertical & 2.000 & 1.850 \\
\hline $3: 2$ & 1.939 & 1.810 \\
\hline $3: 1$ & 1.936 & 1.836 \\
\hline $1: 1$ & 1.873 & 1.776 \\
\hline
\end{tabular}

(Source: USBR, 1987) [9]

Round-crested weir spillway ( 1 crest and 2 crests) is depicted in Figure 2. This type of weir has a higher discharge coefficient (44\%) compared to the coefficient of a width threshold type weir. During flood discharge, the shape of the round-crested weir benefits the river because it can reduce the water level upstream. For round-crested weir 2 radius (R2) (Figure 2), the 
downstream crest part is used to find the value of the discharge coefficient (Risman et al., 2016) [3].

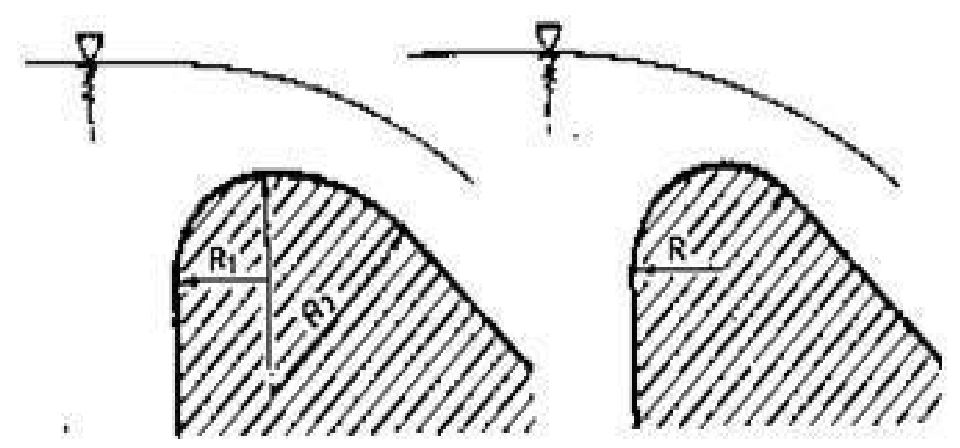

Figure 2. Cross-section of the Round-Crested Weir of One Radius and Two Radius

((Source: Irrigation Planning Standards, KP-02, 2015) [6]

Both types of weir crest can be used in concrete and masonry construction or combination construction. To measure discharge, the equation used for the round-crested weir is as follows:

$$
\mathrm{Q}=\mathrm{C}_{\mathrm{d}} \frac{2}{3} \sqrt{\frac{2}{3}} \mathrm{~g} \mathrm{~b}_{\mathrm{e}} \mathrm{H}_{1}^{1.5}
$$

Where :

Q : Discharge $\left(\mathrm{m}^{3} / \mathrm{s}\right)$

$\mathrm{C}_{\mathrm{d}} \quad$ : coefficient of discharge $\left(\mathrm{Cd}=\mathrm{C}_{0} \cdot \mathrm{C}_{1} \cdot \mathrm{C}_{2}\right)$

G : Gravity acceleration, $9.81\left(\mathrm{~m} / \mathrm{s}^{2}\right)$

$\mathrm{B}_{\mathrm{e}} \quad$ : Effective width of the weir (m)

H1: Height energy above the weir (m)

$$
\mathrm{H}_{1}=\mathrm{h}_{1}+\frac{V_{o}^{2}}{2 g}
$$

where: h1 is the upstream water level above the weir, which is the position of h1 at a distance of $3 \mathrm{H}_{1}$ max as illustrated in Figure 3. 


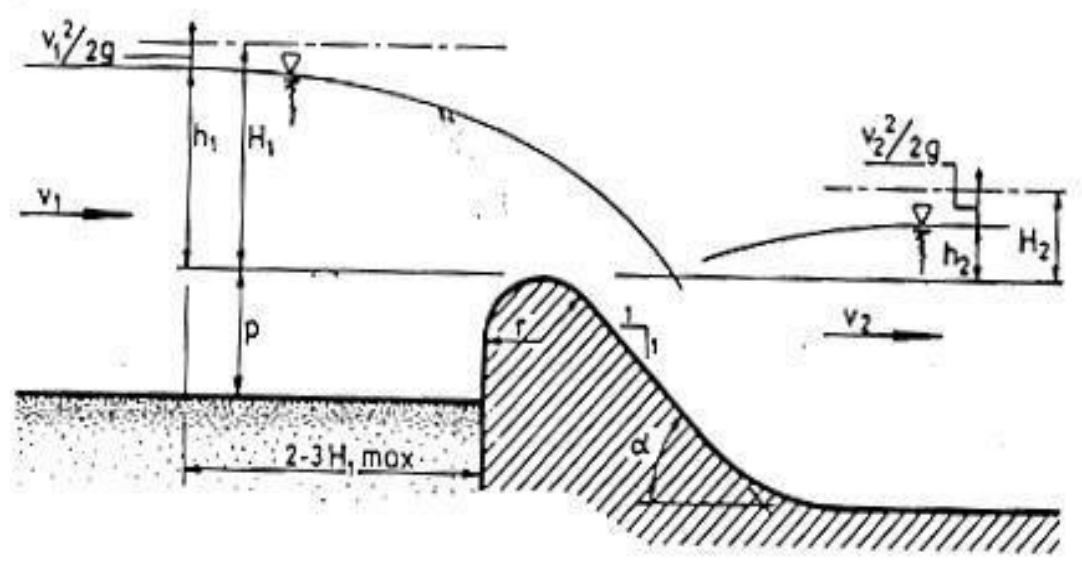

Figure 3. Dam with round-crested weir

(Source: Irrigation Planning Standards, KP-02, 2015) [6]

The coefficient of discharge $\mathrm{C}_{\mathrm{d}}$ for round weir is the multiplication product of:

- $\mathrm{C}_{0}$ which is a function of $\mathrm{H}_{1} / \mathrm{r}$ (see Figure 4)

- $\mathrm{C}_{1}$ which is a function of $\mathrm{p} / \mathrm{H}_{1}$ (see Figure 5)

- $\mathrm{C}_{2}$ which is a function of $\mathrm{p} / \mathrm{H}_{1}$ and the weir of the upstream slope face (see Figure 6).

$\mathrm{C}_{0}$ has a maximum value of 1.49 if $\mathrm{H}_{1} / \mathrm{r}>5.0$ (as shown in Figure 4). If the weir is quite high above the average leading channel ( $\mathrm{p} / \mathrm{H} 1>$ approximately 1.5), then the $\mathrm{C}_{0}$ value in Figure 4 is deemed valid. Before weirs are constructed, in determining the $p$ value, it can take half of the distance from the weir to the foundation of the average channel. For the value of $\mathrm{p} / \mathrm{H}_{1}<1.5$. Thus, in determining the reduction factor $\mathrm{C}_{1}$, it is displayed in Figure 5. (Risman, et al., 2016) [3].

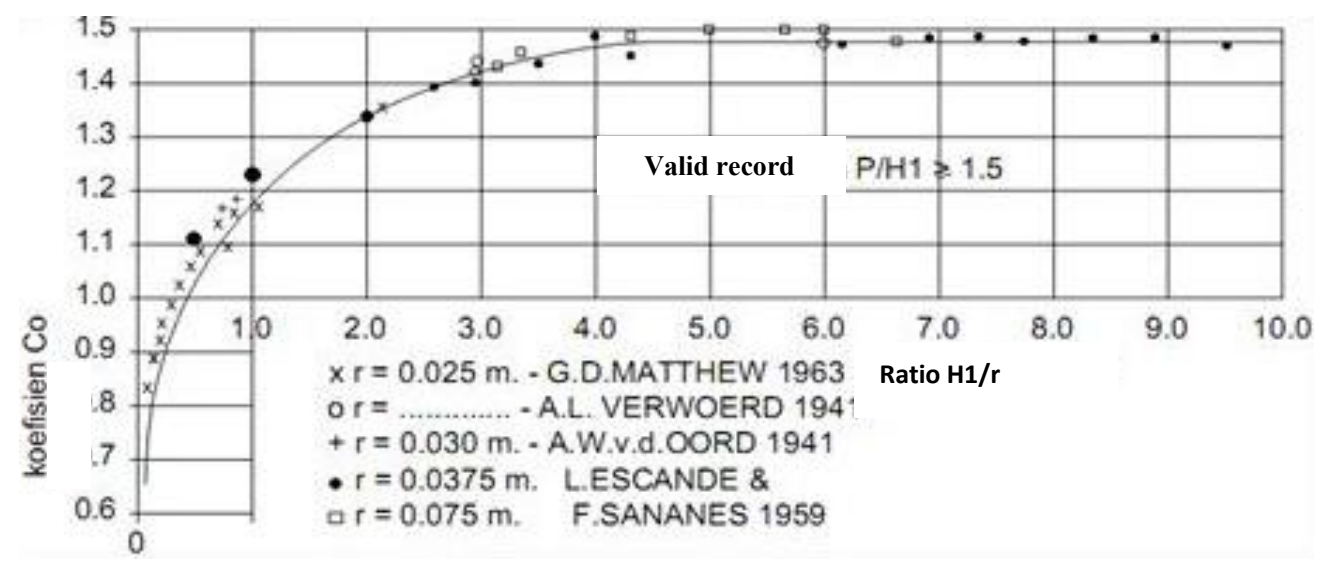

Figure 4. The $\mathrm{C}_{0}$ coefficient for round-crested weir as a function of the $\mathrm{H}_{1} / \mathbf{r}$ ratio 
(Source: Irrigation Planning Standards, KP-02, 2015) [6]

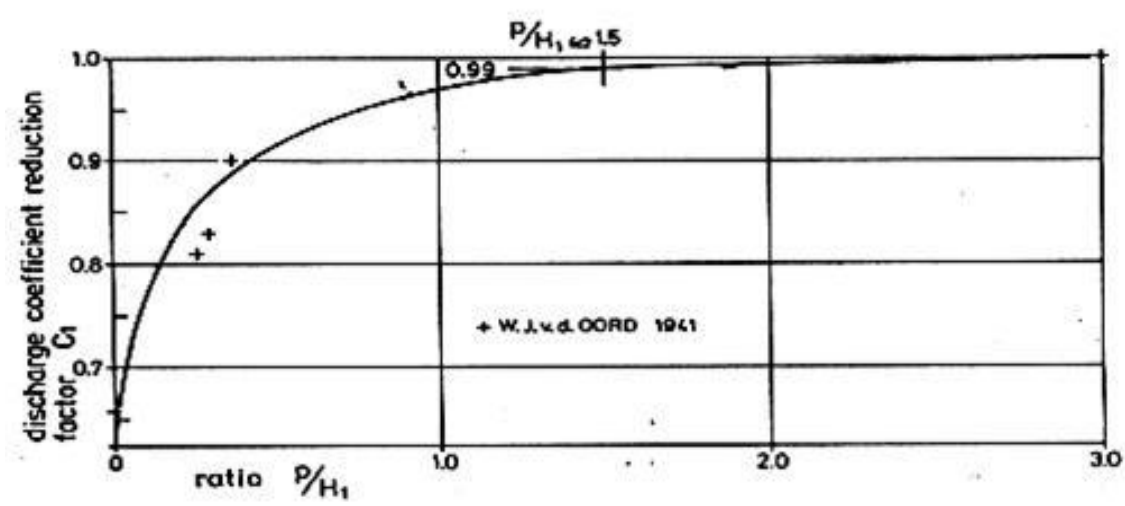

Figure 5. The $\mathrm{C}_{1}$ coefficient as a function of the $\mathrm{p} / \mathrm{H}_{1}$ ratio

(Source: Irrigation Planning Standards, KP-02, 2015) [6]

The correction coefficient value of the upstream slope face of weir effect on the discharge can be seen in Figure 6 and the correction coefficient value of $\mathrm{C} 2$ is considered equal to the correction factor value for the Ogee weir (Risman, et al, 2016) [3].

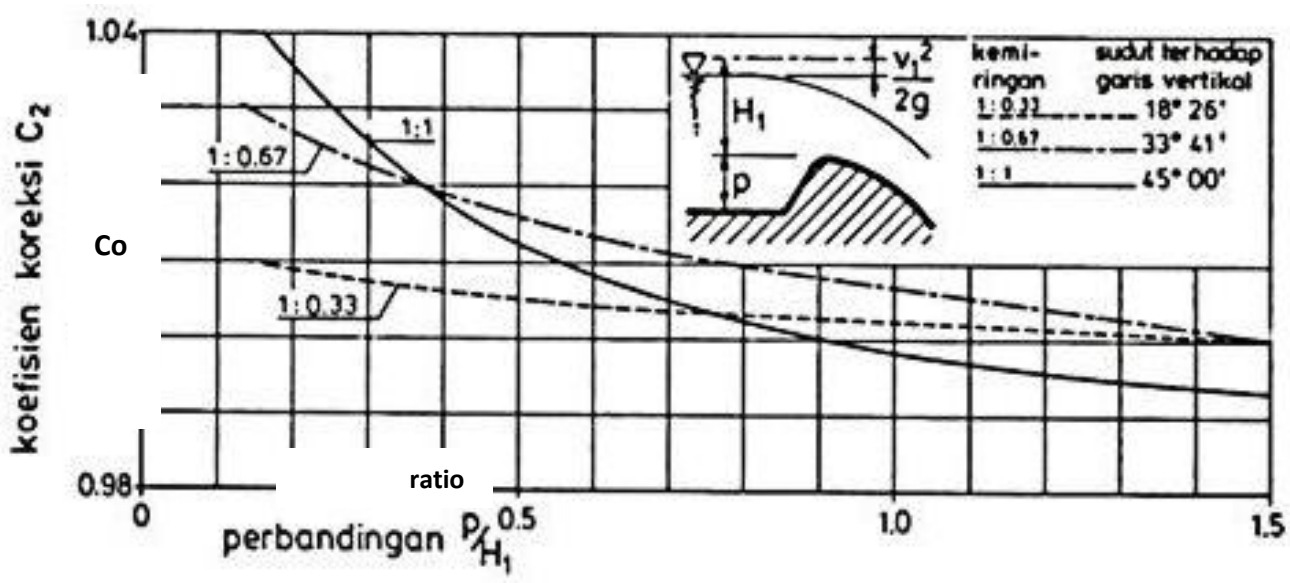

Figure 6. The C2 coefficient value for the Ogee weir with a curved upstream face

(Source: USBR, 1987). [9]

As for the Ogee lighthouse, $C_{d}$ can be measured using the Ogee spillway weir, considering $\mathrm{p} / \mathrm{H}_{1}$ where $\mathrm{p}=$ height of the weir as shown in Figure 3 (for round crest weir) and Figure 7 (for Ogee weir). 


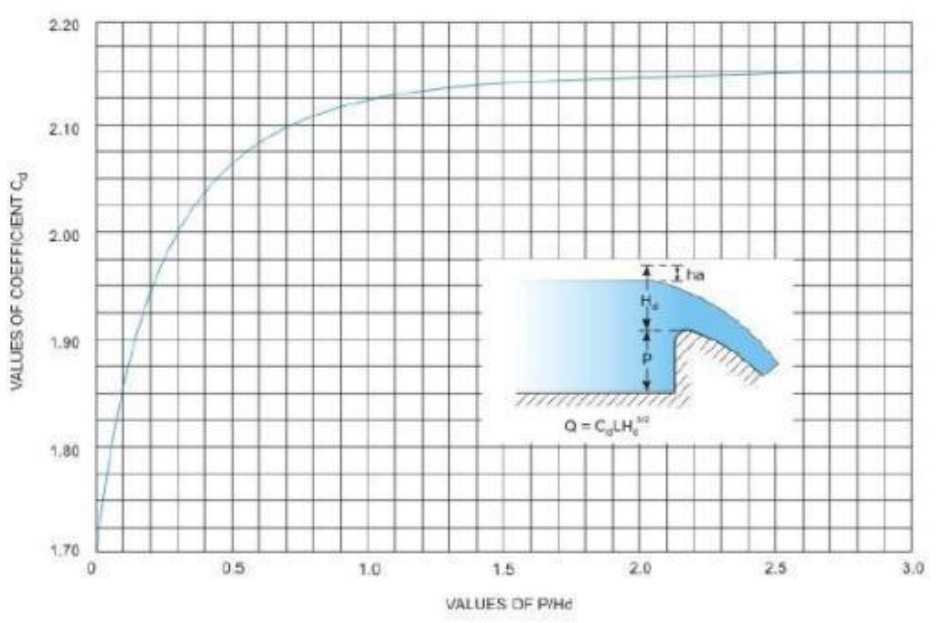

Figure 7.Graph of Ogee spillway weir Coefficient and its relationship between $\mathrm{p} / \mathrm{hd}$

(Source: Hydraulic structures for Flow Diversion and Storage, CE IIT-version 2-Kharagpur, 1995) $[10]$

For round-crested weir 2 radius (R1 and R2) (see Figure 2), the downstream crest is used to find the value of the discharge coefficient (Source: USBR, 1987) [9]. The value of R1 $=0.3$ $\mathrm{H}_{1}$ and $\mathrm{R} 2=2 \mathrm{R} 1$.

The stilling basin length planning calculates the hydraulic jump length using the formula:

$$
\mathrm{Lj}=5\left(\mathrm{n}+\mathrm{y}_{2}\right)
$$

Where :

$\mathrm{L}_{\mathrm{j}} \quad=$ Length of stilling basin $(\mathrm{m})$

$\mathrm{n} \quad=$ Height of the end sill $(\mathrm{m})$

$\mathrm{y}_{2}=$ Depth of water above threshold $(\mathrm{m})$

The height required for this threshold is applied as a function of the Froude number, the depth of the incoming water at the beginning of the jump, and the water level downstream. Thus, the following equation is obtained:

$$
\frac{y_{2}}{y_{u}}=\frac{1}{2} \times\left(\sqrt{1+8 F r_{1}^{2}}-1\right)
$$

Where :

$\mathrm{y}_{2}=$ water depth above the threshold $(\mathrm{m})$

$\mathrm{y}_{\mathrm{u}} \quad=$ water depth in the upstream $(\mathrm{m})$ 
Fr1 = Froude's number before the jump

This research used stilling basin type USBR-I, in which the type has a Froude number $<2.5$. The structure of the stilling basin includes a simple structure consisting of the ground floor of stilling basin and the end sill. Froude's number is formulated as follows:

$$
F r_{l}=\frac{\mathrm{v}_{1}}{\sqrt{\mathrm{gy}_{\mathrm{u}}}}
$$

Where :

$$
\begin{array}{ll}
\text { Frl } & =\text { Froude's number before the jump (on weir downstream) } \\
\mathrm{v}_{1} & =\text { initial velocity of the jump }(\mathrm{m} / \mathrm{s}) \\
\mathrm{y}_{\mathrm{u}} & =\text { Depth of water at the initial hydraulic jump }(\mathrm{m}) \\
\mathrm{g} & =\text { Gravitational acceleration }\left(\mathrm{m} / \mathrm{s}^{2}\right)
\end{array}
$$

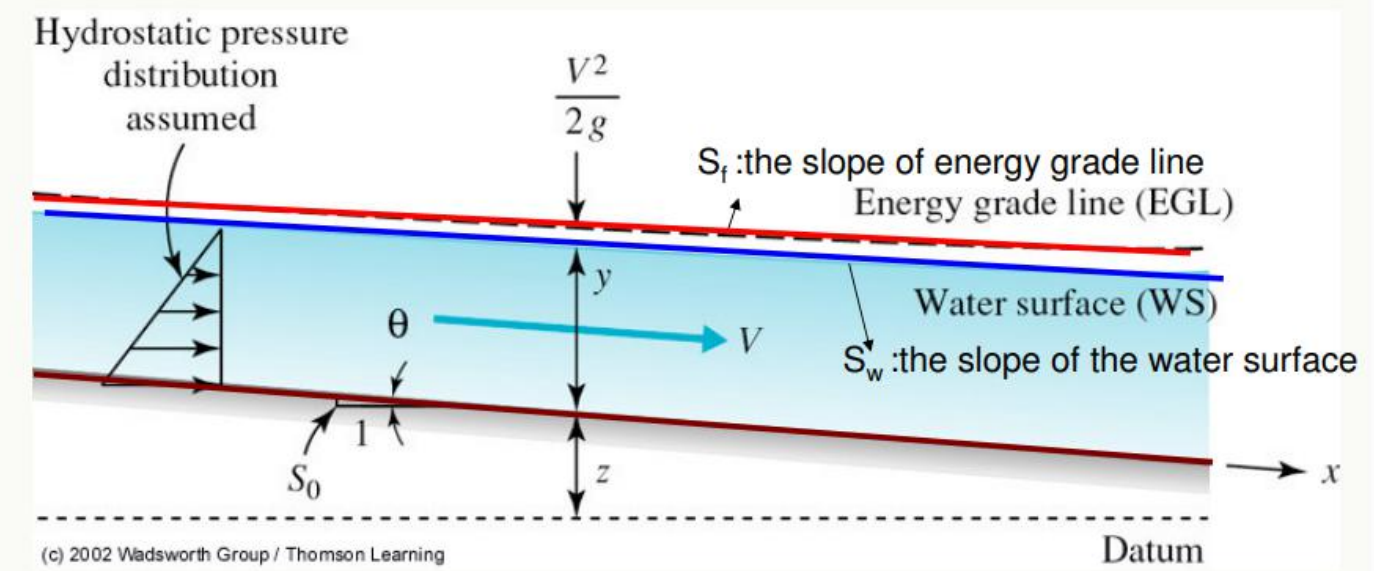

Figure 8. The Energy in the Open Channel Flow Changes Regularly

(Source: /http://web.iku.edu.tr/ asenturk/) [11]

Based on Bernoulli's principle, the total power at each point on the channel is the sum of elevation, pressure, and velocity, see Figure 8. Energy loss, according to Bernoulli, can occur due to friction between the liquid and the boundary wall (hf) or due to changes in the vertical area of the flow. Based on the principle of energy conservation, the high amount of energy in cross-section 1 upstream will be equal to the high amount of energy in cross-section 2 downstream plus the high amount of hf (energy loss), hence, the energy equation for Bernoulli is:

$$
z_{1}+d_{1}+\frac{v_{1}^{2}}{2 g}=z_{2}+d_{2}+\frac{v_{2}^{2}}{2 g}+h f
$$


Where :

$\mathrm{z}_{1} \quad$ : height of point $\mathrm{A}$ on the equation area of cross-section $1(\mathrm{~m})$

$\mathrm{d}_{1} \quad$ : depth of point A below the surface measured across cross-section $1(\mathrm{~m})$

$\mathrm{v}_{1} \quad$ : average flow velocity through A on cross-section $1(\mathrm{~m} / \mathrm{s})$

$\mathrm{Z}_{2} \quad$ : height of point $\mathrm{A}$ on the equation area at cross-section $1(\mathrm{~m})$

$\mathrm{d}_{2} \quad$ : flow velocity through point $\mathrm{A}$.

V2 : depth of point A below surface measured across cross-section $1(\mathrm{~m})$

g : gravitational acceleration $\left(\mathrm{m} / \mathrm{s}^{2}\right)$

hf : energy loss due to friction (m)

\section{METHOD}

This study employed primary data from laboratory testing using a Recirculating Flume instrument of $10.0 \mathrm{~m}$ long, $0.30 \mathrm{~m}$ wide channel, and $0.60 \mathrm{~m}$ flume height as shown in Figure 9.

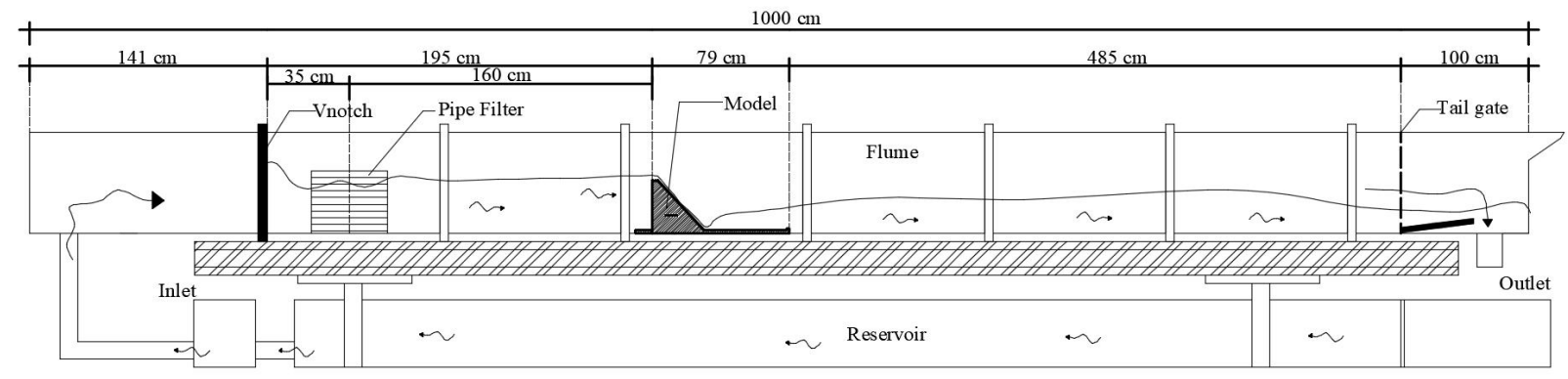

a. Sketch of horizontal cut flume with weir model

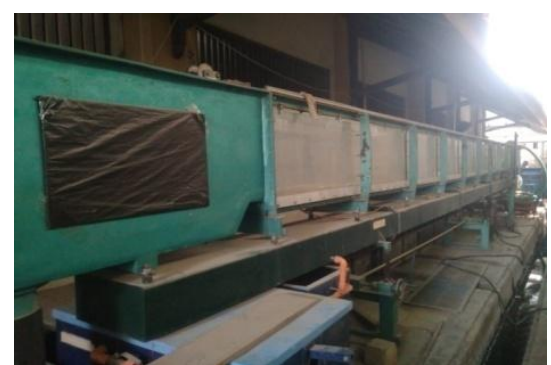

b. Flume Inlet

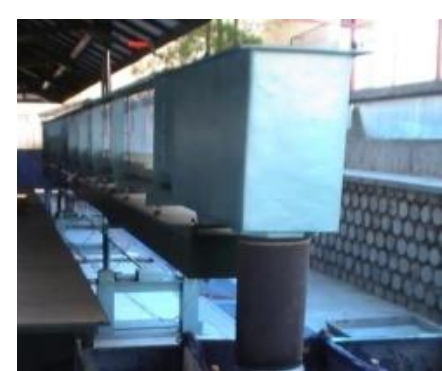

c. Flume Outlet

Figure 9. Recirculating flume channel 
As for the design of the test object model, planning for three variations of the spillway weir model was performed, which are Ogee type (O), round-crest 1 radius type (B.1), and roundcrest 2 radius type (B.2) with the stilling basin type USBR-I. The spillway construction was planned using the maximum discharge from the five debit variations $(\mathrm{Q})$. The following is the calculation of the Ogee spillway construction planning using the equations in the theoretical basis above and the following data with the maximum discharge $(\mathrm{Q})=0.005 \mathrm{~m}^{3} / \mathrm{s}$; channel width $(b)=0.3 \mathrm{~m}$; spillway height $(\mathrm{P})=0.30 \mathrm{~m}$; trial $\mathrm{h} 1=0.03834 \mathrm{~m}$, obtains:
a. Initial velocity, $\mathrm{V}_{\mathrm{o}}=0.04926 \mathrm{~m} / \mathrm{s}$
b. Total pressure, $\mathrm{H}_{\mathrm{e}}=0.03846 \mathrm{~m}$
c. Find the $\mathrm{C}_{\mathrm{d}}$ coefficient using the graph in Figure 7.

From the graph in Figure 7, it obtained the value of the discharge coefficient of Ogee $C_{d}=$ 2.209, thus the discharge control (Q) is:

$\mathrm{Q}=\mathrm{C}_{\mathrm{d}} \times \mathrm{bxh} \mathrm{h}_{\mathrm{e}}^{3 / 2}=0,005 \mathrm{~m}^{3} / \mathrm{s}(\mathrm{ok})$

Round-crest spillway planning ( 1 crest and 2 crests) with maximum discharge data $(\mathrm{Q})=$ $0.005 \mathrm{~m}^{3} / \mathrm{s}$; effective channel width $\left(B_{e}\right)=0.3-0.4 \mathrm{H} 1$; discharge coefficient $\left(C_{d}\right)=C_{0} . C_{1} . C_{2}$ $=1.3$, yields:

a. Energy above the weir $\left(\mathrm{H}_{1}\right), \mathrm{Q}=\mathrm{C}_{\mathrm{d}} \cdot \frac{2}{3} \sqrt{\frac{2}{3} \mathrm{~g}} \cdot \mathrm{B}_{\mathrm{e}} \cdot \mathrm{H}_{1}^{\frac{2}{3}}$. acquires $\mathrm{H}_{1}=0.03973 \mathrm{~m}$

b. Find the weir radius, $\mathrm{R} 1=0.3 \times \mathrm{H} 1=0.012 \mathrm{~m}$, see Figure 10 .

c. Find the weir radius, $\mathrm{R} 2=2 \times \mathrm{R} 1=0.024 \mathrm{~m}$, see Figure 11 .

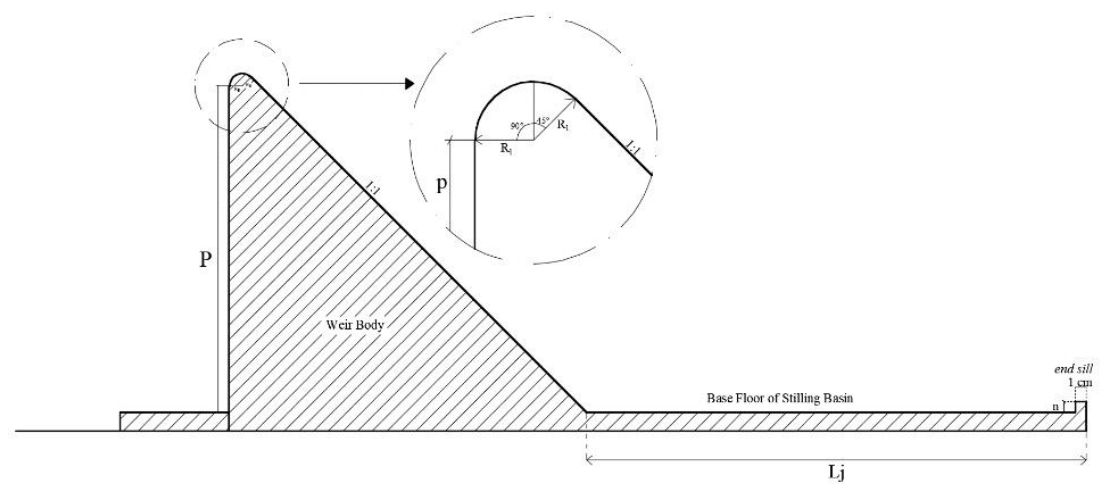

Figure 10. Weir area of round crest 1 radius 


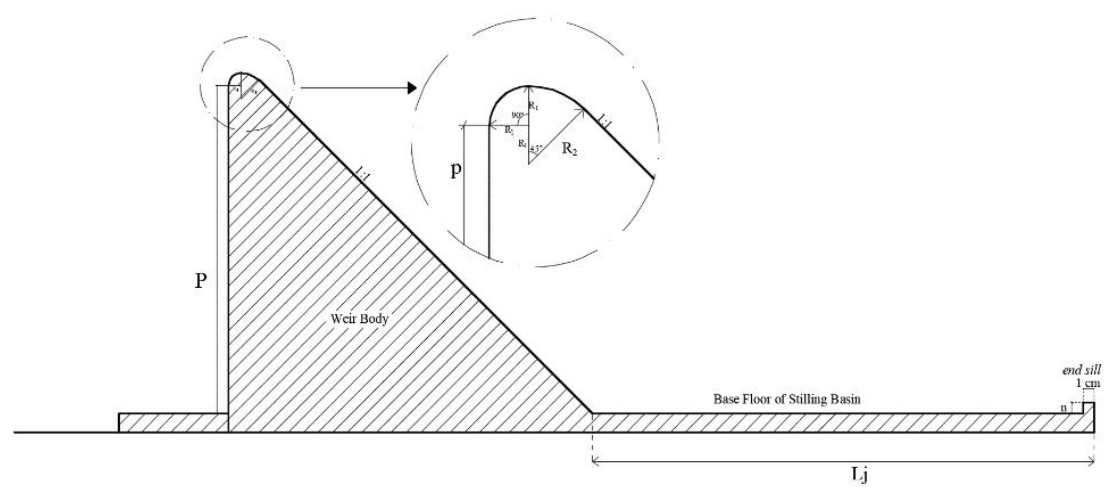

Figure 11. Weir area of round crest 2 radius

The next plan is to build stilling basin. The following is the calculation of the USBR-I stilling basin for the Ogee type spillway with the maximum discharge data $(\mathrm{Q})=0.005 \mathrm{~m}^{3} / \mathrm{s}$; channel width (b) $=0.3 \mathrm{~m}$; spillway height $(\mathrm{P})=0.3 \mathrm{~m} ; \mathrm{h}_{\mathrm{d}}=0.03834 \mathrm{~m} ; \mathrm{g}=9.81 \mathrm{~m} / \mathrm{s} 2 ;$ stilling basin thickness $(\mathrm{s} 1)=0.017 \mathrm{~m}$, obtains:

a. $\quad$ End sill Height $=\mathrm{n}=0.01 \mathrm{~m}$

b. The length of stilling basin $(\mathrm{Lj})=0.49 \mathrm{~m}$

\section{RESULTS AND DISCUSSION}

Next, the results of this study were analyzed using equations/formulas and graphically depicted thus drawing conclusions. Measurement of the spillway discharge was conducted by flowing water through the flume by considering the discharge control valve in the laboratory using five variations of discharge from $3000 \mathrm{~cm}^{3} / \mathrm{s}, 3500 \mathrm{~cm}^{3} / \mathrm{s}, 4000 \mathrm{~cm}^{3} / \mathrm{s}, 4500 \mathrm{~cm}^{3} / \mathrm{s}$, and $5000 \mathrm{~cm}^{3} / \mathrm{s}$ and analysis includes the following descriptions.

\subsection{Flow Velocity Analysis with Discharge Variations}

The upstream weir velocity is $v_{0}$, velocity above the weir is $v_{1}$, and velocity at the initial jump is $v_{u}$, while $v_{2}$ is the downstream weir velocity or above the end sill. To earn the velocity data above, the flow depth was observed at each point. A detailed explanation of the location of the flow depth observation is presented in Figure 12 below. 


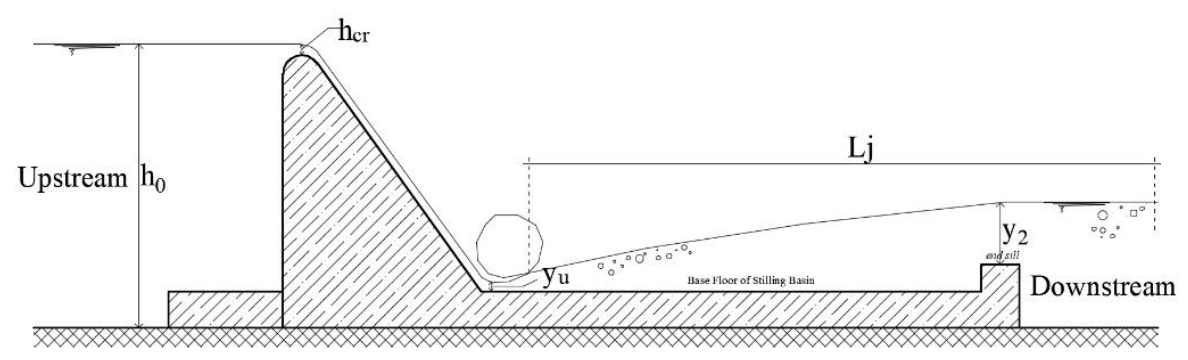

Figure 12. The depth of the upstream weir flow $\left(h_{0}\right)$, above the weir $\left(h_{c r}\right)$, initial jump $(y u)$, and downstream weir (y2)

After the observation of the flow depth, the flow velocity at each point was obtained. The velocity in each variation of weir type consisted of a velocity corresponded to the discharge, in which the greater the discharge, the greater the speed is. The following is an example of a relationship graph between discharge and velocity in the Ogee-type weir.

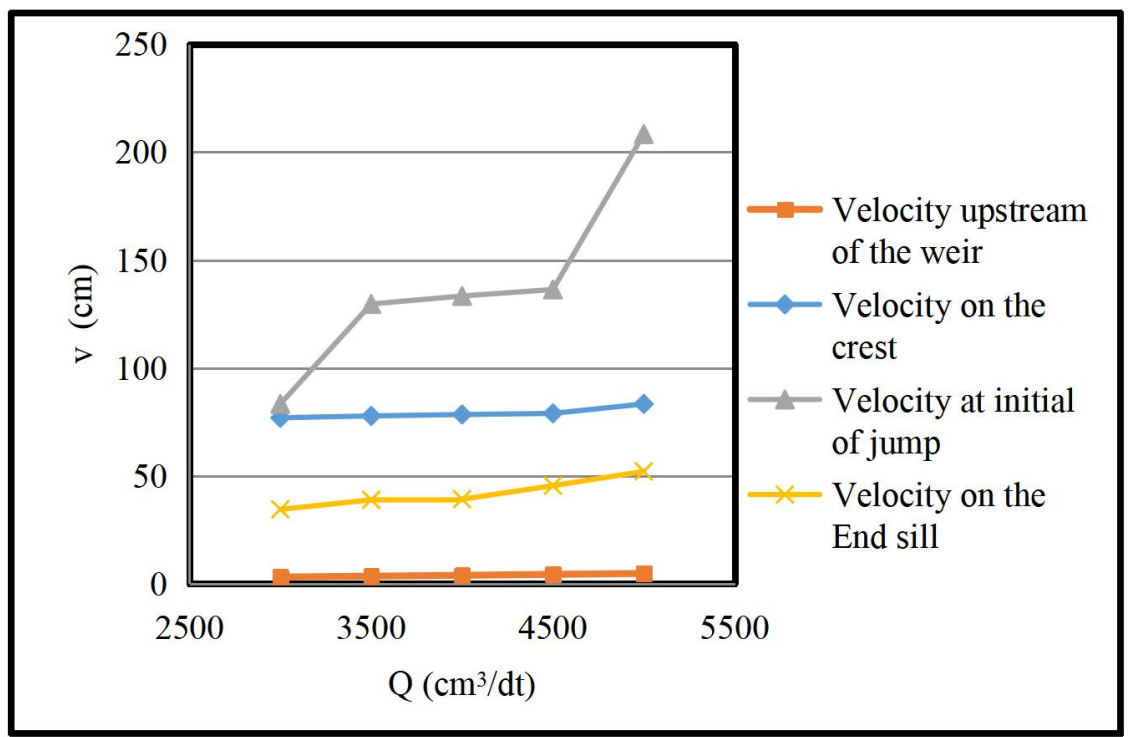

Figure 13. Relationship between Discharge Variation $Q\left(\mathrm{~cm}^{3} / \mathrm{s}\right)$ and Flow Velocity v $(\mathrm{cm})$ in Ogee (O) weir

In Figure 13, it can be determined that the velocity in Ogee weir, especially at the initial jump, did not go smoothly compared to the others. It occurred due to uneven friction on the weir body. 


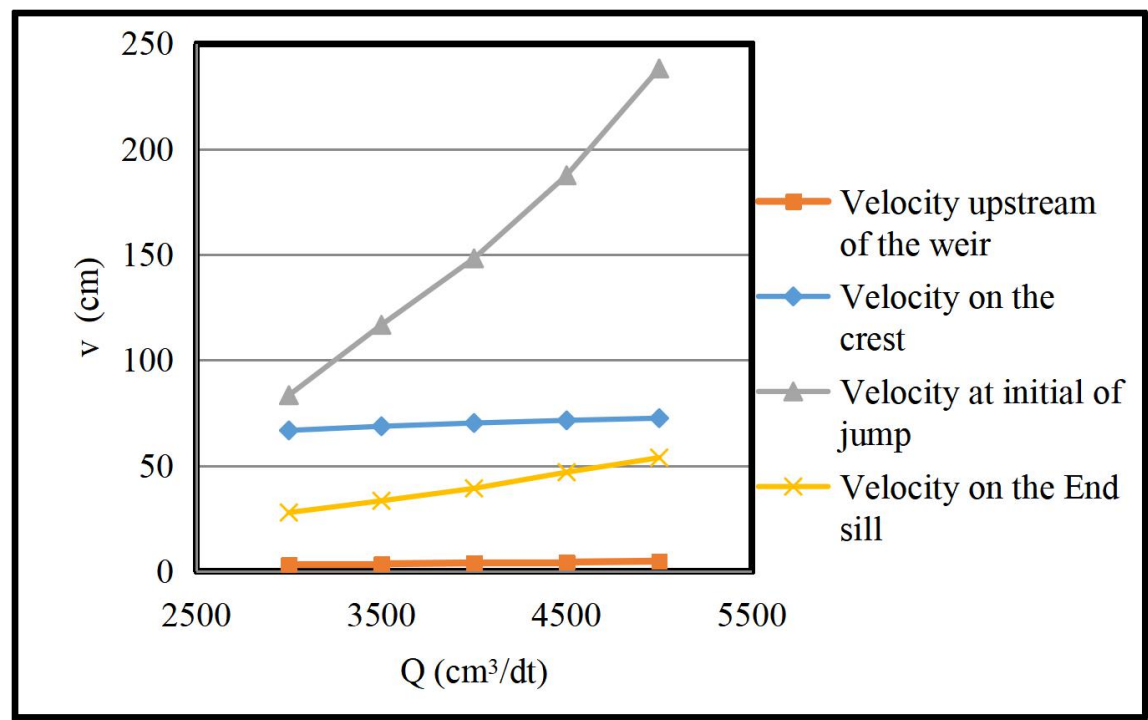

Figure 14. Relationship between Discharge Variation $Q\left(\mathrm{~cm}^{3} / \mathbf{s}\right)$ and Flow Velocity $\mathbf{v}(\mathrm{m})$ in Round Crest 1 Radius Weir (B.1).

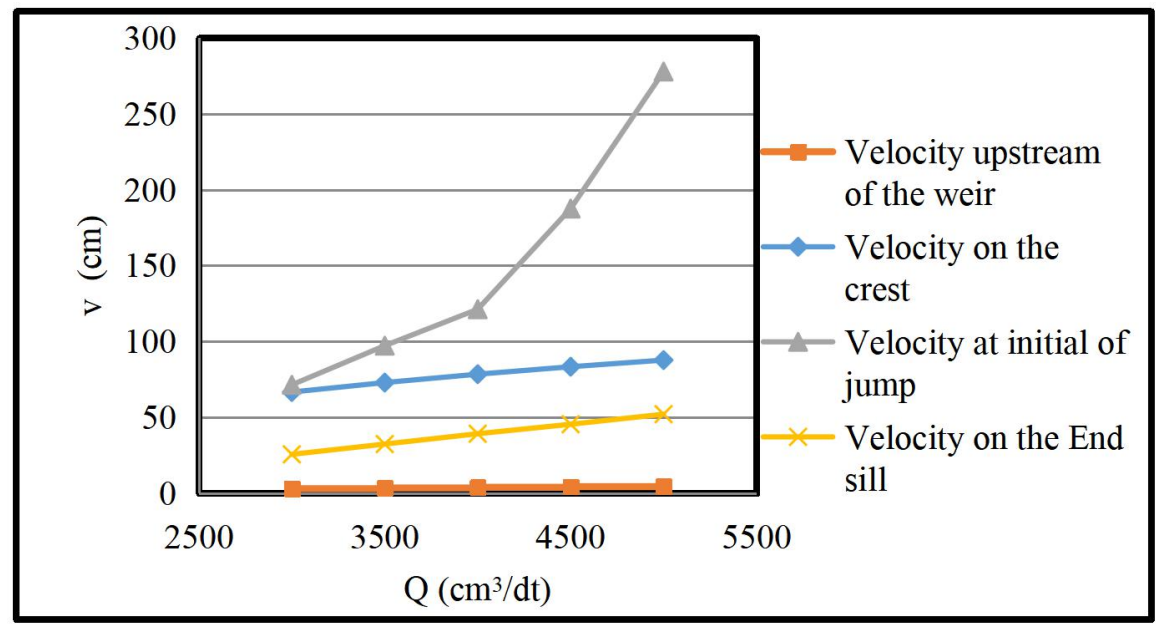

Figure 15. Relationship between Discharge Variation $Q\left(\mathrm{~cm}^{3} / \mathrm{s}\right)$ and Flow Velocity $\mathbf{v}(\mathrm{m})$ in

\section{Round crest 2 Radius weir (B.2).}

If the flow velocity studies for three weirs as in Figure 13, Figure 14, and Figure 15 are compared, the figures show that for the same discharge that the upstream weir velocity, above the weir, and above the end-sill display correspond velocity value. Whereas the velocity at the initial jump shows a very different value, in which round-crest radius 2 weir (B.2) has a greater speed than the round-crest 1 radius weir (B.1) and the Ogee weir $(\mathrm{O})$, then the order of values is the round-crest 1 radius and followed by Ogee weir.

Based on the analysis of the figures above, the 2 radius weir has a fairly large energy dissipation compared to others because there is a fairly large change (difference) between the 
velocity at the initial jump and the velocity at the downstream end-sill. So, it will be studied in energy loss analysis.

\subsection{Analysis of Froude Numbers with Discharge Variations}

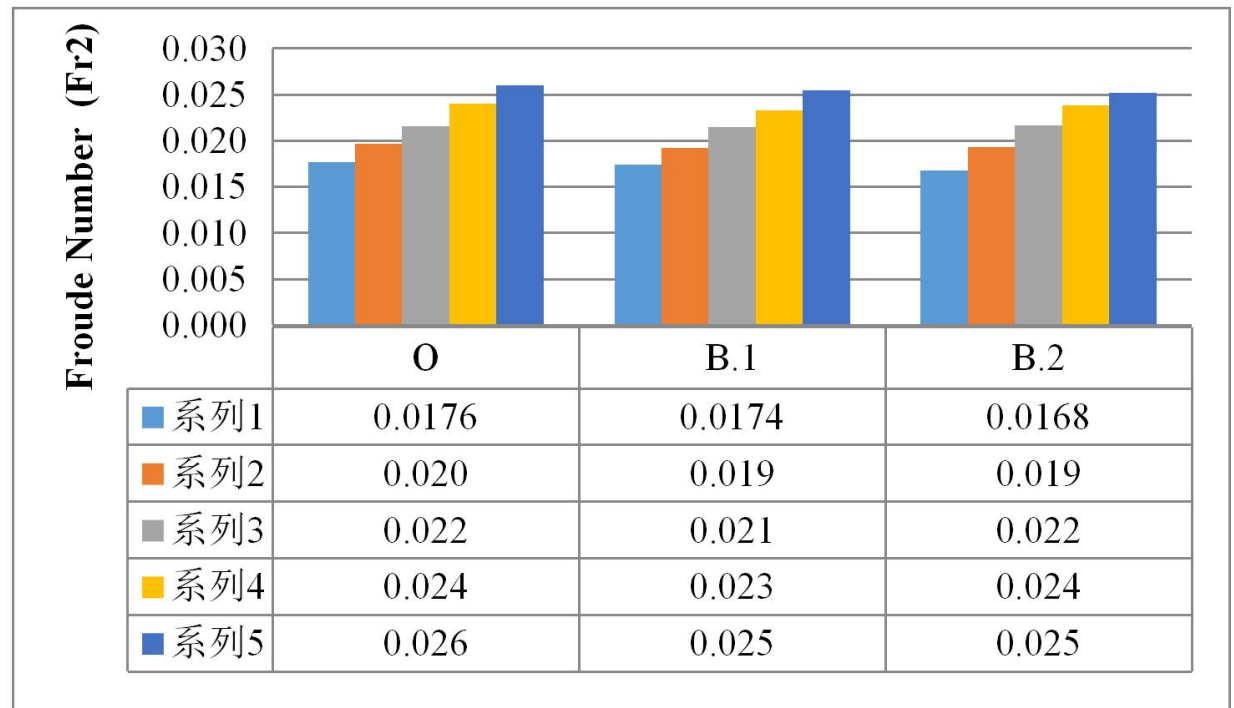

Figure 16. Relationship between Discharger Variation $\left(\mathrm{cm}^{3} / \mathrm{s}\right)$ and Froud Number $\left(\mathrm{Fr}_{1}\right)$ in the upstream on the three variations of weirs with USBR-I stilling basin

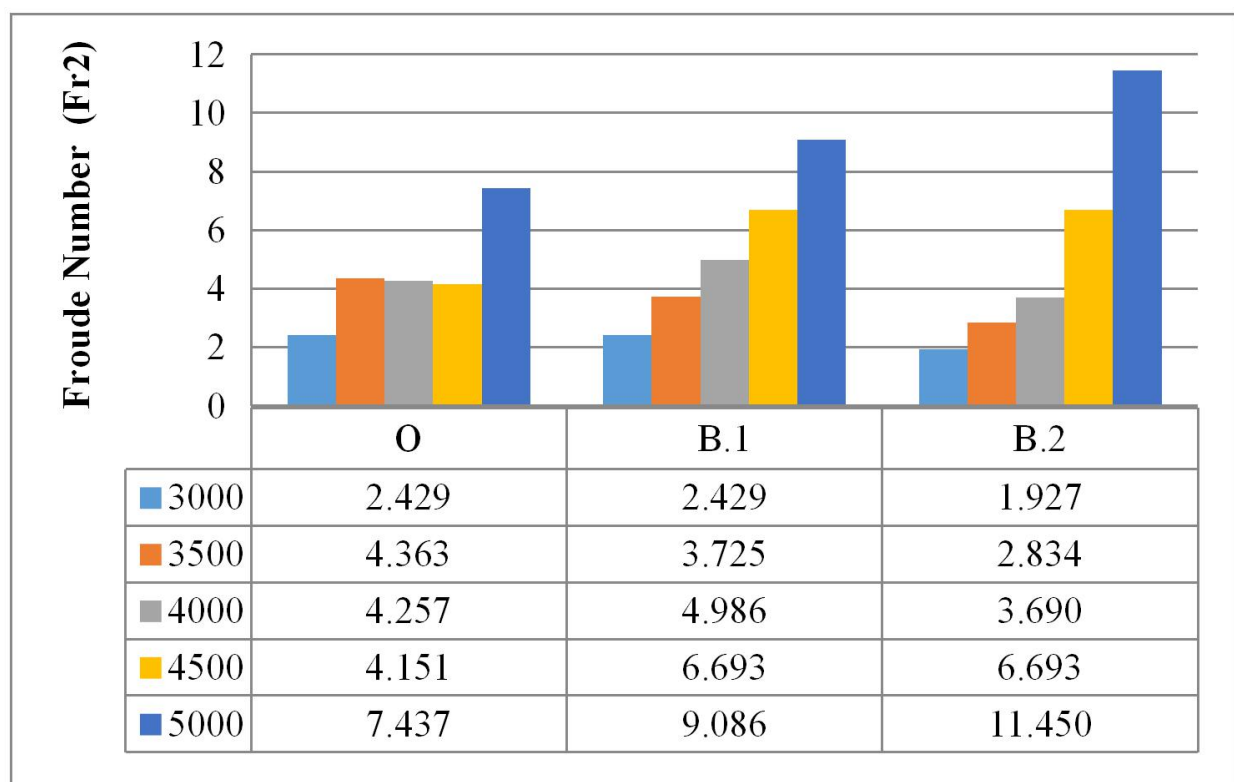

Figure 17. Relationship between Discharger Variation $\left(\mathrm{cm}^{3} / \mathrm{s}\right)$ and Froud Number $\left(\mathrm{Fr}_{2}\right)$ at the initial jump on the three variations of weirs with USBR-I stilling basin 


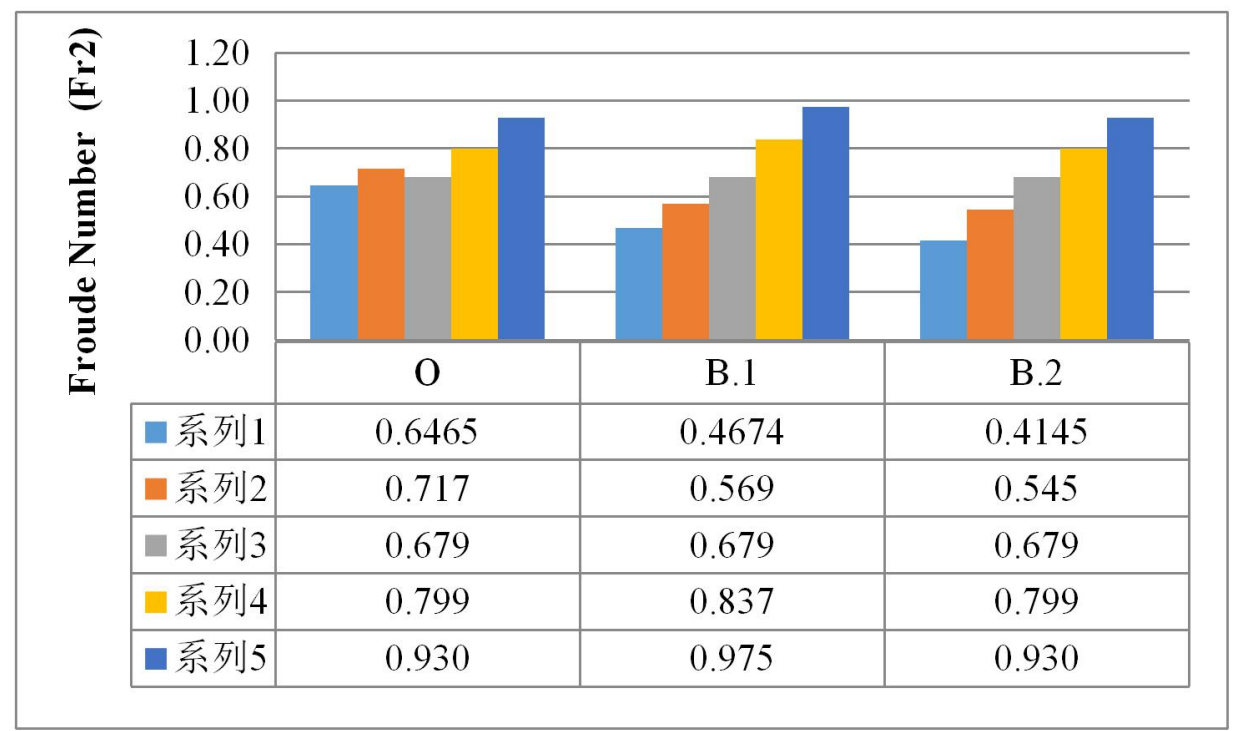

Figure 18. Relationship between Discharger Variation $\left(\mathrm{cm}^{3} / \mathrm{s}\right)$ and Froud Number $\left(\mathrm{Fr}_{3}\right)$ above end sill on the three variations of weirs with USBR-I stilling basin

Figure 16 shows that the greater the discharge $(\mathrm{Q})$, the greater the Froude number is. Whereas Figure 17 and Figure 18 shows that in variation one, which is the Ogee-type weir, it appears that the relationship between the discharge and the Froude number is less stable. The event is probably due to the unstable flow velocity ( $v$ ) at some point of observation as a result of uneven friction with the glass wall making the flow is slightly obstructed and the flow elevation at the initial jump (yu) increases. Flow characteristics in open channels based on the value (Fr) are categorized into three; subcritical flow, if the Froude number (Fr) $<1$; critical flow, if the value $(\mathrm{Fr})=1$; and supercritical flow, if the value $(\mathrm{Fr})>1$. The Ogee $(\mathrm{O})$ weir, if the upstream Froude number $(\operatorname{Fr} 1)$ has the mean value of $\operatorname{Fr} 1<1$, meaning that the upstream flow is subcritical, while if the Froude number downstream has the average value of Fr2>1, it implies that the downstream flow is supercritical.

\subsection{Analysis of Energy Loss with Discharge Variation}




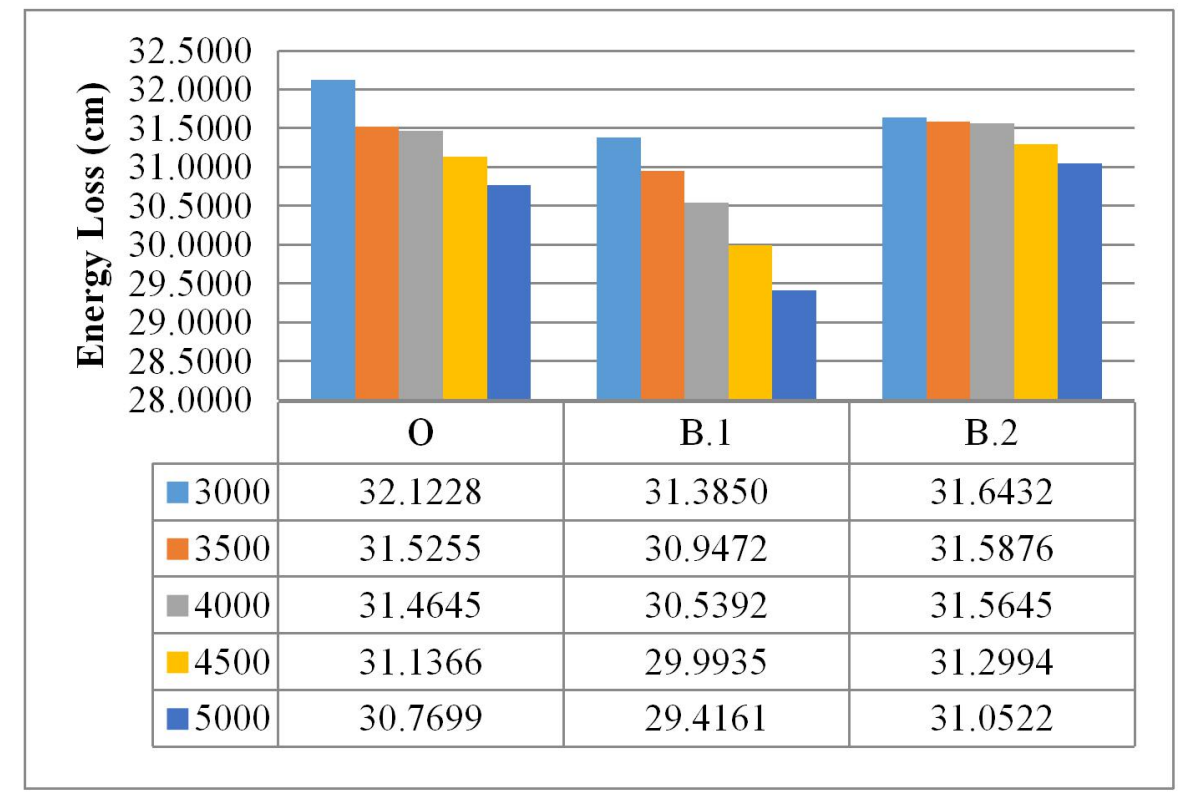

Figure 19. Relation of Flow Variation ( $\mathrm{cm} 3$ / s) with Energy Loss (cm)

Figure 19 implies that the three variations of weir constructions have the ability to dissipate different energy. The greater the energy loss in the channel signifies a better level of energy dissipation. Thus, it can be concluded that the most effective variation of the weir in dissipating energy is the third variation, which is the round crest 2 radius weir (B.2). It is because type B.2 weir has the highest average energy loss value among the three variations of weirs. In order, the best variations in dissipating energy are the round crest 2 radius weir (B.2), Ogee weir (O), and round crest 1 radius weir (B.1).

\subsection{Analysis of hydraulic jump length with discharge variations}

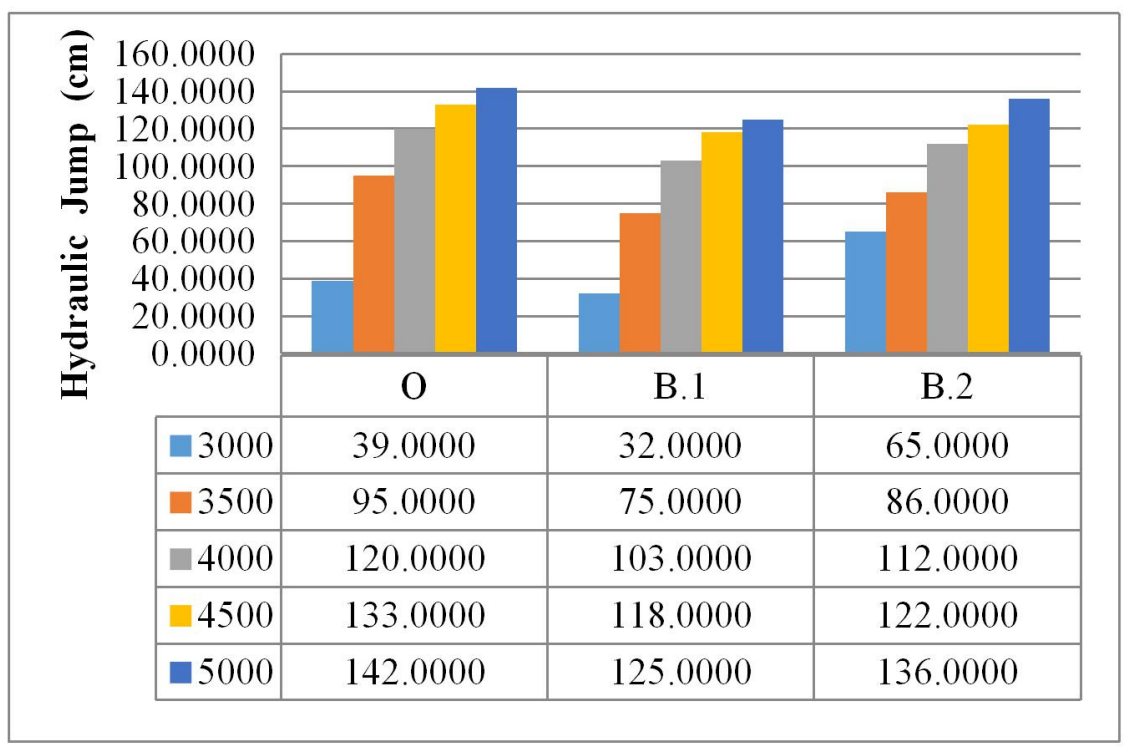

Figure 20. Relationship between Discharge Variation $\left(\mathrm{cm}^{3} / \mathrm{s}\right)$ with 


\section{Hydraulic Jump Length (cm)}

Figure 20 shows that all weir variations have the same pattern. The greater the discharge, the greater the length of the hydraulic jump. The graph also shows the most effective weir variation in dissipating hydraulic jump, which is round0-crest 1 radius weir (B.1). It is based on the judgment that this weir has the shortest average jump length value compared to the other three weir variations. In sequence, the most effective variations in reducing the length of the jump are round-crest 1 radius weir (B.1), round-crest 2 radius weir (B.2), and Ogee weir (O).

\section{CONCLUSION}

The results of the study obtain conclusions as follows.

1. The greater the discharge, the greater the Froude number (Fr) and the length of the hydraulic jump are. However, ogee (O) weir has an unstable Froude number (Fr). So that this variation is not effective to dissipate energy.

2. Based on the analysis of energy loss (hf) and analysis of jump length (Lj), the most effective variation of the test object for energy dissipation is the round-crest 2 radius weir (B.2) because the greater the energy loss and the smaller the length of a hydraulic jump, the better the energy dissipation will be.

3. Based on the analysis of the value of the Froude number (Fr), the value (Fr1) in the upstream weir has an average value of $\operatorname{Fr} 1<1$, thus the flow upstream is subcritical. The transition to the initial jump has an average value of $\operatorname{Fr} 2>1$, which denotes that the flow downstream is supercritical. Finally, the downstream weir after the stilling basin has a mean value of Fr3 $<1$, making it returns to subcritical.

\section{ACKNOWLEDGMENT}

We would like to thank Mr. A. Karim Fatchan as the head of the Civil Engineering Laboratory, Faculty of Engineering, Universitas Muhammadiyah Surakarta to provide permission to use hydraulic laboratory equipment, as well as assistants who help so this research completion. 


\section{REFERENCES}

[1] Abdurrosyid, Jaji, et.all. 2018. "Influence of Baffle Block and Weir Downstream Slope at Stilling Basin of Solid Roller Bucket Type on Hydraulic Jump and Energy Dissipation”. AIP Conference Proceedings 1977, 040031 (2018); https://doi.org/10.1063/1.5043001

[2] Abdurrosyid, Jaji dan Pratiwi P D. 2020. "Kajian Pengaruh Slotted dan Baffle Blocks pada Kolam Olak Roller Bucket Terhadap Peredam Energi”. Jurnal Dinamika Teknik Sipil, Vol 3, No 1 (2020): 1-9; http://journals.ums.ac.id/index.php/DTS/issue/view/1063

[3] Risman, dkk. 2017. "Kajian Perilaku Aliran Melalui Alat Ukur Debit Mercu Bulat Terhadap Tinggi Muka Air”. Skripsi. Semarang: Fakultas Teknik, Politekhnik Negeri Semarang.

[4] Ihsan, M. Kabir, 2017. "Pengaruh Bentuk Mercu Bendung Terhadap Tinggi Loncat Air Kolam Olak Model USBR IV (Simulasi Laboratorium)”. Teras Jurnal, Vol 7, No 1 (2017) : 173-182.

[5] Nurjanah, R.A Dita. 2014. "Analisis Tinggi dan Panjang Loncat Air pada Bangunan Ukur Berbentuk Setengah Lingkaran”. Skripsi. Sumatera Selatan: Fakultas Teknik, Universitas Sriwijaya.

[6] Irrigation Planning Standards/ Standar Perencanaan Irigasi (KP-02), 2015. Kriteria Perencanaan Bagian Bangunan Utama. Jakarta: DPU, Dirjen Pengairan.

[7] Novak, P., et.al. 1996. Hydraulic Structure. Oxford : Alden Press.

[8] Abdurrosyid, Jaji dkk. 2009. "Studi Gerusan dan Perlindunganya di Hilir Kolam Olakan Bendung Tipe USBR-I”. Jurnal Dinamika Teknik Sipil, Terakreditasi BAN, Vol 9, No 1 (2009) : 27-37

[9] USBR, 1987. Design of Small Dams. $3^{\text {rd }}$ ed., Denver: US Government Printing Office. USA.

[10] Kharagpur, 1995. Hydraulic Structures for Flow Diversion and Storage, New Delhi: CE IIT, version 2.

[11] http://web.iku.edu.tr/ asenturk/Microsoft PowerPoint-open-channel1.pdf 